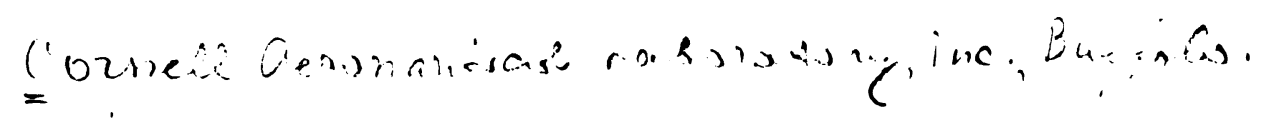

NAVSHIPS 900,190

\title{
GUIDE MANUAL OF COOLING METHODS FOR
}

\section{ELECTRONIC EQUIPMENT}

\section{BUREAU OF SHIPS NAVY DEPARTMENT WASHINGTON 25, D. C.}

For sale by the Superintendent of Documents, U. S. Government. Printing Office Washington 25, D. C. - Price $\$ 2.00$ 